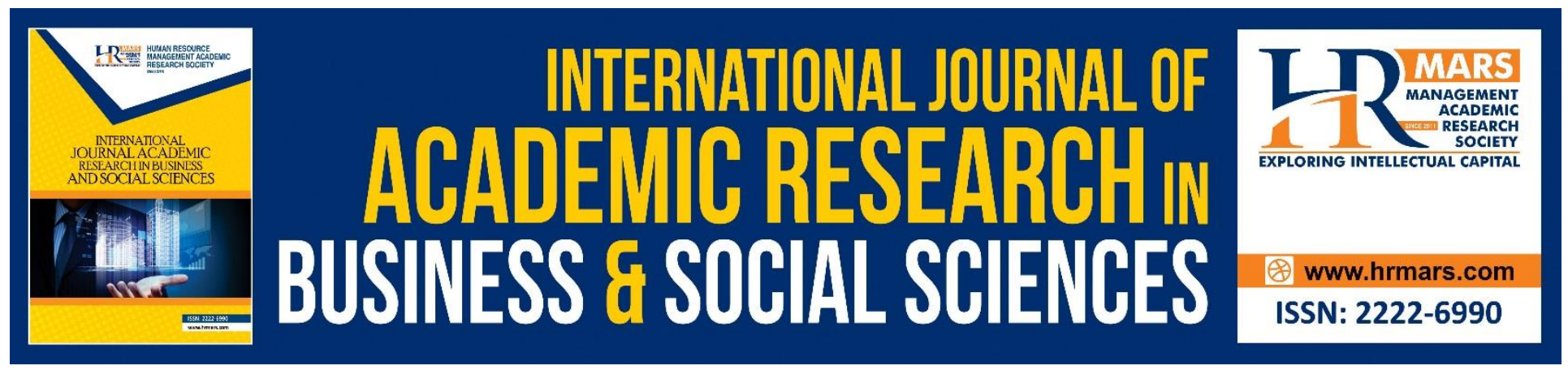

\title{
Imagined Communities and the Construction of National Identity
}

\author{
Idola Perdini Putri, Ellisha Nasruddin, Juliana Abdul Wahab
}

To Link this Article: http://dx.doi.org/10.6007/IJARBSS/v8-i7/4399

DOI: $\quad 10.6007 /$ IJARBSS/v8-i7/4399

Received: 26 May 2018, Revised: 19 June 2018, Accepted: 29 June 2018

Published Online: 18 July 2018

In-Text Citation: (Putri, Nasruddin, \& Wahab, 2018)

To Cite this Article: Putri, I. P., Nasruddin, E., \& Wahab, J. A. (2018). Imagined Communities and the Construction of National Identity. International Journal of Academic Research in Business and Social Sciences, 8(7), 565572.

Copyright: (C) 2018 The Author(s)

Published by Human Resource Management Academic Research Society (www.hrmars.com)

This article is published under the Creative Commons Attribution (CC BY 4.0) license. Anyone may reproduce, distribute, translate and create derivative works of this article (for both commercial and non-commercial purposes), subject to full attribution to the original publication and authors. The full terms of this license may be seen at: http://creativecommons.org/licences/by/4.0/legalcode

Vol. 8, No. 7, July 2018, Pg. 565 - 572

http://hrmars.com/index.php/pages/detail/IJARBSS

JOURNAL HOMEPAGE

Full Terms \& Conditions of access and use can be found at http://hrmars.com/index.php/pages/detail/publication-ethics 


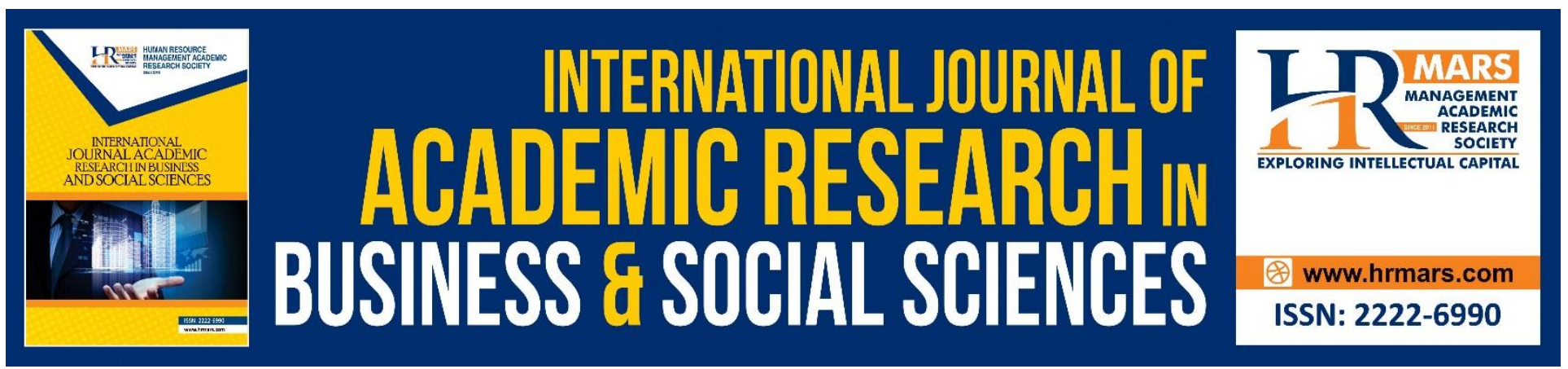

\title{
Imagined Communities and the Construction of National Identity
}

\author{
Idola Perdini Putri \\ Communication Program Study, Communication and Business Faculty, Telkom University, Bandung, \\ Indonesia \\ Email: idolaputri22@gmail.com \\ Dr. Ellisha Nasruddin \\ Assoc. Prof, Graduate School of Business, University Sains Malaysia, Penang, Malaysia \\ Email: ellisha@usm.my \\ Dr. Juliana Abdul Wahab \\ Assoc. Prof, Communication School,University Sains Malaysia, Penang, Malaysia \\ Email:julia@usm.my
}

\begin{abstract}
Nationalism and nation are the important concept in construct the term of national identity. Benedict Anderson claims that nation as such is always imagined communities that give their members/citizens a sense of identity and belonging. Anderson believes that community actively builds the concept of nation, that a nation is a socially constructed community, imagined by the people who perceive themselves as part of that group. The sense of society on national identity is imagined through communities same experience. In Anderson perspective, the shared experience can be achieves through the role of mass media. Postmodern and globalization era, was facilitates the new form of media, that increasingly the possibility of society in experiencing the same idea. The argument of media as catalyst in form the society commonness, said, in other word, that mass media has important role in form the notion of national identity. Mass media presence helped people perceive themselves as homogeneous body. Mass media shared the idea among a nations and its people. Anderson have identified that mass media is a key instrument in the social construction of imagined communities. Media representations are integral to the social construction of national identities. However, mass media also eliminates the geographical boundaries among community. The form of national identity will influence either by internal forces and external forces. Moreover, within the condition, new narratives can change people's perceptions of what constitutes their national identity.
\end{abstract}


INTERNATIONAL JOURNAL OF ACADEMIC RESEARCH IN BUSINESS AND SOCIAL SCIENCES Vol. 8, No. 7, July 2018, E-ISSN: 2222-6990 @ 2018 HRMARS

Keywords: Imagined Communities, National Identity, Nationalism, Nation, Postmodern, Globalization, Mass Media.

\section{Introduction}

The concept of Benedict Anderson imagined communities was first published in 1983, tries to describe the ideas, reasons, histories, and even discussion on the rise of nation states and nationalism in newer perception. Imagined communities provided a macro-level analysis of the processes by which nationalism arose and spread in early modern (Phillips, 2002). He shows how a community was formed into one nation under the proof of nationalism as an ideology to unite the diversity that imagining. Anderson (2006) define nation as an imagined community since "the members of even the smallest nation will never know most of their fellow-members, meet them, or even hear of them, yet in the minds of each lives the image of their communion" (p. 6). However, the members of the community are sharing the sameness in order to forge the notion of national identity, thus the nationalism is not a natural awakening of existing nation but the invention of one.

The nation perceive as community because the nation is always conceived as a deep, horizontal comradeship (Anderson, 2006), even though they never meet. Imagined communities as Anderson wrote, for example, is how Javanese villagers always know that they connected to people they have never seen also told us how community does not always means face to face interaction. The practice of print-capitalism as a catalyst in share the sameness without practices the face to face interaction facilitated the imagining of the nation. Anderson argues that the expansion of print languages created unified fields of communication, which enabled speakers of a diverse variety of languages to become aware of one another via print and paper (Anderson, 2006). Print-capitalism also gave fixity to language, which stabilized it and gave print language a sense of antiquity that enhanced the feeling of nationalism (Lo, 2012). The members of community, consequently, became aware of the existence of the millions who share their nation and language.

Nationalism is the image of nation that creates national identity. Smith (1991) explained nationalism as "an ideological movement for attaining and maintaining autonomy, unity and identity on behalf of a population deemed by some of its members to constitute an actual or potential 'nation'” (p. 73). A nation, writes Anderson, is imagined because the members of even the smallest nation will never know most of their fellow-members, meet them, or even hear of them, yet in the minds of each lives the image of their communion (Anderson, 2006). Anderson argues that people whom consume same media they begin to perceive something in common (Anderson, 2006). This commonness then leads to the idea on society of notion of national identity.

\section{Imagined Communities}

Anderson concept drawing an attention to the issue of the personal sense of national identity and belonging, focus on the imagined quality of the nation, an emphasis that reflected his boarder concern with the emergence of a new way of experiencing community, based upon indirect (rather than face to face) social relationships (Phillips, 2002; Calhoun, 1991). The community possible to imagined by the individual, because the social conditions that made this national form were the emergence of print language, in interaction with capitalism and human linguistic diversity (Anderson, 2006). The spread of print materials made people aware towards the existence of one to another groups.

The concept of print capitalism as an catalyst in sharing the sameness, looking through at the western condition, when it was begun in Europe in which print machine was invented, and then used 
INTERNATIONAL JOURNAL OF ACADEMIC RESEARCH IN BUSINESS AND SOCIAL SCIENCES Vol. 8, No. 7, July 2018, E-ISSN: 2222-6990 @ 2018 HRMARS

to print translated version into many languages so that people with their lingua franca could understand the text (Hansen, n.y). These phenomena showed the rise of national consciousness that was developed because of, the similarity towards the language in print media, at the pre-modern era (Sietzy, n.y). Yet, the development, furthermore not only appeared in European countries but also outside Europe such as Asian and Africa within the Western imperialism or colonization era around the world. In the colonial states, the print materials were used to record information about people under colonization, like census, firstly for races, religions, as well as traditions, which purposed to map the society (Wogan, 2001). Later, the system was actually adapted by the government in the independent nation state or ex-colonized country, to ease them apply the programs as well as what to do to penetrate the ideology of nationalism (Tan, 2012). The print media encourage the development of community sense of national identity.

Anderson employed the term print capitalism to designate the way nation-states increasingly became institutionalized through the production, distribution and general utilization of printed representations from the nineteenth century (Hansen, n.y). In the other hand, by the 1990s, globalization studies developed a set of new conditions for the postmodern re-conceptualization of citizenship (Kymlicka, 2010). Beck argues that we are now living in a global risk society where the threats to our well-being are increasingly coming from human-made technology rather that natural disaster (Beck, 2011). The technological changes, such as an internet have created time-space compression, which changing the concept of nation-state and national citizenship in the context of globalization (Sparke, 2005). And, in the end, the maps and other visual depictions of nation-states to delimit the geographies of nation as imagined communities plays roles in shaping national identity (Anderson, 2006).

Moreover, in the twenty first century, currently the popularity of print media has been replaced by the digital media. Before the today digital media, Arjun Appadurai mentioned the electronic capitalism in order to replace the term of print capitalism around twenty century. Appadurai mentioned the term electronic capitalism to encompass the changes in media technology, especially the role of television, radio and the initial version of the Internet (Appadurai, 1996). Among the features of electronic capitalism highlighted by Appadurai the aural and visual elements encompass a strong potential for the emotional engagement of target groups and potentially having a greater outreach towards audiences, while specific language skills as in the case of written media are not required (Hansen, n.y). Today, in globalization era the Internet has spawned a number of new challenges, opportunities and a new terminology for researchers of ethnic identity and nationalism, such as cyber-ethnography, electronic or Internet nations, virtual communities, digital Diasporas, etc. The digital media was also create new society, condition that Marshal Mc Luhan introduced us as global village term, digital society that usually audiences or public named by cyber communities/citizen (Logan, 2016). We no longer need searching foreign people in foreign country to find an example, this community consist of people in somewhere area around the world.

The concept of national identity within imagined national communities, as Anderson shows, are based on the invention and mass production of the printed book. In his work, Anderson postulated that the origin of nationalism lies in language, with the rise of mass literacy, development of printing and press capitalism, as well as the rising modernization within the colonial society (Anderson, 2006). According to the concept of imagined communities the convergence of capitalism and print technology abolish the ideas of nationalism (Wogan, 2001). Anderson concept drawing an attention to the issue of the personal sense of national identity and belonging, focus on the imagined quality of the nation, an emphasis that reflected his boarder concern with the emergence of a new 
INTERNATIONAL JOURNAL OF ACADEMIC RESEARCH IN BUSINESS AND SOCIAL SCIENCES Vol. 8, No. 7, July 2018, E-ISSN: 2222-6990 @ 2018 HRMARS

way of experiencing community, based upon indirect (rather than face to face) social relationships (Phillips, 2002; Calhoun, 1991). The community possible to imagined by the individual, because the social conditions that made this national form were the emergence of print language, in interaction with capitalism and human linguistic diversity (Anderson, 2006).

Anderson employed the term print capitalism to designate the way nation-states increasingly became institutionalized through the production, distribution and general utilization of printed representations from the nineteenth century (Hansen, n.y). Therefore, in Anderson's perspective, the shared experience can be achieves through the role of mass media. Mass media increase the possibility of society in experiencing the same idea. And within the society changes, the development and Anderson argues that people whom consume same media begin to perceive something in common (Anderson, 2006). This commonness leads to the idea of national identity notion. Mass media presence helped people perceive themselves as homogeneous body (ibid.). Mass media shared the idea among a nations and its people. Mass media providing their audience with narratives that unfold in specific places, they give them a sense of community, as well as a sense of shared history and identity (Baumgartel, 2011). The common experience build among people in society in the end will forge the notion of national identity.

However, in the other hand, by the 1990s, globalization studies developed a set of new conditions for the postmodern re-conceptualization of citizenship (Kymlicka, 2010). Beck argues that we are now living in a global risk society where the threats to our well-being are increasingly coming from human-made technology rather that natural disaster (Beck, 2011). The technological changes, such as an Internet have created time-space compression, which changing the concept of nationstate and national citizenship in the context of globalization (Sparke, 2005). And, in the end, the maps and other visual depictions of nation-states to delimit the geographies of nation as imagined communities play roles in shaping national identity (Anderson, 2006). Moreover, in the twenty first century, currently the popularity of print media was replace by the digital media.

Before the today digital media, Arjun Appadurai mentioned the electronic capitalism in order to replace the term of print capitalism around twenty century. Appadurai mentioned the term electronic capitalism to encompass the changes in media technology, especially the role of television, radio and the initial version of the Internet (Appadurai, 1996). Among the features of electronic capitalism highlighted by Appadurai the aural and visual elements encompass a strong potential for the emotional engagement of target groups and potentially having a greater outreach towards audiences, while specific language skills as in the case of written media are not required (Hansen, n.y). Film production and consumption, in this term, can lead to the conception of common culture that can unify the nation-state (Carter, 2008). Film has great potential in create the term of national identity since film allows people to shared experiences.

\section{Imagined Communities, National Identities and Film}

The imagining of the nation, which traced to media representations, forged through common languages and understandings. The imagined community of the nation exists because its members have internalized media representations of the nation. Film and cinema said can only exist within social, economic, and cultural parameters. Film production necessarily involve in the discourse making within the cultural forms represent in the film. While, economic relations within an industrialcommercial and the socio-political realities within the production and circulation also taking place in the process of national identity portrayal in film. 
INTERNATIONAL JOURNAL OF ACADEMIC RESEARCH IN BUSINESS AND SOCIAL SCIENCES Vol. 8, No. 7, July 2018, E-ISSN: 2222-6990 @ 2018 HRMARS

Egyptian films was used to validate the Egyptian national identity, and films represent the national myths and symbols that bind a nation together (Khatib, 2006). Meanwhile, the directors' background as actors in creating the discourse on national identity in films also considered. In creating images of identity, the director selects fragments of reality and wraps them in ideas, fantasies, and understanding, shaping them with the help of cinematographic and social stereotypes (Semikhat, 2010). Therefore, social, including gender, roles represented in a film text can be examined from the point of view of their broader societal significance. Society today actively developing means of mass communication and visual media.

On the other hand, the role of film is also underlines in constructing the discourse of national identity. The symbols of national identity reflect from the film representation of society conditions, historical conjunctures and sub-cultures portrayal, meanwhile the film language is used on analysing the national identity in narrative form. (Harman, 2016). Moreover, territory elements also said as an important site to engage audience to the certain discourse of national identity (Berry, 2016).

Pema Tseden's films use the trope of the journey through a homeland to examine the relationship between the protagonist and audience. Pema's Tibetan movies display a culture in crisis resulting from the encounter with modernity and protagonists who are not so much alienated from their culture as unsure of where it is going, where it should go, and how they should be involved with this process. The research underlines the territory importance in the development of national identity sense among the audience. Furthermore the research also mentioned the strong relationship between the culture attached to the territory in their role on develop the nostalgic memory to their nation. Furthermore, there is closely relationship between places and the form national identity (Scharf, 2005).

Independent film is a replacement of novels or newspaper due to Anderson concept of media catalyst in forming the nation members' sense of national identity (Baumgartel, 2011). He used the concept of Anderson imagined community to explained the territory elimination in the process of national identity building among the international audience. He argues that independent film made by Southeast Asia filmmakers never recognize in their own country, rather that acknowledge more in international audience. The filmmakers said to be making the imagined worlds that bound the international audience into same discourse on certain national identity. Baumgartel explain on how this imagined worlds work in forge the national identity using Appadurai concept of global cultural flows. He conclude that most of the national identity notion are contradict with the national identity description promotes by their government. The notion seems to be resistance to the officially prescribed identity in their homeland country.

Meanwhile, the nation representation can describes draw on Anderson imagined communities and Billig's banal nationalism concept. Through the national symbols consist of territory, language, flag, name, gastronomy, national days. The importance of the identified categories of territory and language was clear, while the role of flags and names was dominant (Holland, 2012). Data finding shows that the importance of the identified categories of territory and language was clear, while the role of flags and names was dominant. Two other identified categories (gastronomy and national days) were absent almost completely from the sample. Through regular references to armies, legislatures and other national or nationalised bodies, the role of institutions in The Simpsons was strongly established. Historical figures like national leaders, past and contemporary, were also dominant aspects of the discourse of nation.

Researching concept of Deleuze narrative time also can be used in understanding the notion of national identity in independent film, since independent film tend to be form in twist and unusual 
INTERNATIONAL JOURNAL OF ACADEMIC RESEARCH IN BUSINESS AND SOCIAL SCIENCES

Vol. 8, No. 7, July 2018, E-ISSN: 2222-6990 @ 2018 HRMARS

narrative. However, even, the Deleuze narrative time concept of film suitable for Western countries is not suitable in East countries (Jones, 2006). The postcolonial character of most East countries made the historical or memory of their homeland represent in film more compatible in looking at the portrayal of notion of national identity.

\section{Conclusion}

In summary, the national identity within imagined communities concept identify through different identity lenses such as cultural identity, ethnicity, civic national identity. The concept provide the possibility in forming the multiple national identities, which the bonding of different identity lenses to the one common sense of national identity will more valuable to the multiethnic and multicultural society.

National identity within the imagined communities concept in films represent in the symbols of national myth, territory, language, religion, cultural, historical roots and directors background. The films also build around the external factors within its role as the catalyst in the process of sharing the common national identity sense among the nation members.

In other words, it can be noted that in relations within imagined communities, national identity and independent film, the suggestion underlines the investigation on cultural attributes/belongings/roots; the process of negotiation between the various lenses of identity; the sign and symbols within the film text; and the cultural production on the elements of the cultural producers, the site or location and the political policy.

\section{References}

1. Anderson, B. (2006). Imagined Communities: Reflections on the Origin and Spread of Nationalism. New York, USA: Verso.

2. Appadurai, A. (1996). Modernity at Large: Cultural Dimensions of Globalization. Minneapolis London, UK: University of Minnesota Press.

3. Baumgartel, T. (2011). Imagined communities, imagined worlds: Independent film from South East Asia in the global mediascape independent cinema. Transnational Cinemas, 2(1) 57-71.

4. Beck, U. (2011). Cosmopolitanism as Imagined Communities of Global Risk. American Behavioral Scientist, 55(10) $1346-1361$.

5. Berry, C \& Farquhar, M. (2006). China on Screen: Cinema and Nation. New York, USA: Columbia University Press.

6. Calhoun, C. (1991). Indirect Relationships and Imagined Communities, pp. 95-121 in P. Bourdieu and J.S. Coleman (eds) Social Theory for a Changing Society. Boulder, CO: Westview.

7. Carter, S. G. (2008). Constructing an independent Moroccan nation and national identity through cinema and institutions. The Journal of North African Studies, 13(4) 531-559.

8. Hansen, L. F. (n.d). iCircassia: Digital Capitalism and New Transnational Identities. 1-33.

9. Harman, S. (2016). Stuart Hall: Re-reading Cultural Identity, Diaspora, and Film. Howard Journal of Communications, 27(2), 112-129.

10. Holland, T. (2012). Television Nations: Imagined Communities in the Simpsons. Bachelor Thesis, University of Wollongong. (Published).

11. Jones, D. M. (2006). Deleuze, Cinema and National Identity. Edinburgh, UK: Edinburgh University Press. 
INTERNATIONAL JOURNAL OF ACADEMIC RESEARCH IN BUSINESS AND SOCIAL SCIENCES

Vol. 8, No. 7, July 2018, E-ISSN: 2222-6990 @ 2018 HRMARS

12. Khatib, L. (2006). Nationalism and Otherness: The Representation of Islamic Fundamentalism in Egyptian Cinema. European Journal of Cultural Studies, 9 (1) 63-80.

13. Kymlica, W. (2010). The Rise and Fall of Multiculturalism? New Debates on Inclusion and Accommodation in Diverse Societies. International Social Sciences Journal, 61(199), 97-112.

14. Logan, R. K. (2016). Understanding New Media: Extending Marshall Mcluhan. New York, USA: Peter Lang Publishing.

15. Phillips, T. (2002). Imagined Communities and Self-Identity: An Exploratory Quantitative Analysis. Sociology, 36(3), 597-617.

16. Scharf, I. (2005). Staging the Border: National Identity and the Critical Geopolitics of West German Film. Geopolitics, 10(2), 378-397.

17. Semikhat, E. I. (2010). Gender Specifics of National Imagery in Soviet Film, or National Identity in Mass Culture. Anthropology \& Archeology of Eurasia, 49(2), 76-83.

18. Sietzy, K. (n.d). A Critique of Benedict Anderson's "Imagined Communities".

19. Smith, A. D. (1991). National Identity. Reno, USA: University of Nevada Press.

20. Sparke, M. (2005). Introducing Globalization: Ties, Tensions, and Uneven Integration. New Jersey, USA: Wiley Publishers.

21. Tan, L. (2012). Indonesian National Security During The Suharto New Order (1965-1998): The Role of Narratives of Peoplehood and The Construction of Danger. New Zealand Journal of Asian Studies, 14(1), 49-70.

22. Wogan, P. (2001). Imagined Communities Reconsidered: Is Print-Capitalism What We Think It Is?. Anthropological Theory, 1(4), 403-418. 